\title{
Mineralogy as a critical factor of dust iron solubility
}

\author{
Emilie Journet, ${ }^{1}$ Karine V. Desboeufs, ${ }^{1}$ Sandrine Caquineau, ${ }^{2}$ and Jean-Louis Colin ${ }^{1}$ \\ Received 4 August 2007; revised 22 November 2007; accepted 25 January 2008; published 3 April 2008.
}

[1] To understand the impact of dust deposition on ocean primary productivity, the evaluation of dust input is not sufficient, and the soluble iron supply is also needed. Measurements of iron in aerosols suggest a much higher solubility than in soil, implying substantial atmospheric processing of chemical or physical nature. Here, we have investigated the effect of the mineralogy on iron solubility. We have measured iron solubility from some minerals commonly found in dust (clay, feldspar and iron (hydr-)oxides). Firstly, we observe a greater solubility of iron resulting from clays $(\sim 4 \%)$ in comparison to iron (hydr-)oxides $(<1 \%)$, independently of specific surface of minerals. Secondly, by considering amount of dissolved iron and the mineralogical composition of dust, our results indicate that dissolved iron fraction mainly comes from clay dissolution in contrast to that assumed in some biogeochemical models. In consequence, it appears that iron solubility is closely linked to the mineralogical composition of aerosol. Citation: Journet, E., K. V. Desboeufs, S. Caquineau, and J.-L. Colin (2008), Mineralogy as a critical factor of dust iron solubility, Geophys. Res. Lett., 35, L07805, doi:10.1029/2007GL031589.

\section{Introduction}

[2] Studying iron solubility is important to understand the carbon biogeochemical cycle. Iron is an essential nutrient for marine microorganisms and is critical to ocean primary productivity. By influencing the pCO2 in the atmosphere, the carbon fixation by oceanic biota has a direct impact on Earth's climate system (Wells et al., 1995). Atmospheric deposition, and the notably sporadic dust plume, was identified as the main iron supply, especially in remote oceans (Duce and Tindale, 1991). However, in order to consider the Fe impact on the ocean productivity, the key flux to the oceans is not dust, but soluble iron, which we assume here is the potentially bioavailable fraction. Soluble iron in soils represents about $0.5 \%$ of total iron, but measurements of iron in aerosols suggest a much higher solubility, implying substantial atmospheric processing [Jickells et al., 2005]. Indeed, solubility ranges from $0.01 \%$ to $80 \%$ and are highly heterogeneous in space and time [Mahowald et al., 2005]. Although it is clear that atmospheric processing changes the solubility of iron as it moves from the source regions to be deposited into oceans, the relative importance of the different mechanisms is not clear. On one hand, several studies have emphasized that photochemical reactions, organic complexation and cloud

\footnotetext{
${ }^{1}$ LISA, Universités Paris 7 et Paris 12, CNRS, Créteil, France.

${ }^{2}$ Laboratoire des Formations Superficielle, Institut de Recherche pour le Developpement Bondy, France.
}

Copyright 2008 by the American Geophysical Union. 0094-8276/08/2007GL031589 processes in the atmosphere can modify iron solubility of desert dust [Desboeufs et al., 2001; Chen and Siefert, 2004; Hand et al., 2004]. On the other hand, recent investigations, conducted by Baker and Jickells [2006] suggest that dust iron solubility is rather controlled by particle size than by chemical processes during their atmospheric transport as a result of the increase of surface area to volume ratio of the dust population with distance away from desert source due to higher gravitational settling of largest particles. However, this size discrimination along the dust transport trajectory seems to have also an effect on the mineralogy of dust population. Several studies over Atlantic Ocean emphasize a change of the mineralogical composition of Saharan dust during their transport, with a decrease of quartz relative part in favour of clay fraction [Glaccum and Prospero, 1980]. These authors conclude that it is due to a much faster sedimentation of quartz. The size splitting up process occurring both at the emission and during atmospheric transport induces an increase of relative amount of fine particles and so an increase of relative clay content in dust plume. Over Pacific, Gao et al. [2003] show also by dust deposition modeling that the clay fraction becomes more and more dominant downwind of the sources from Asia.

[3] In this paper, we present an estimation of iron solubility from pure minerals which compose dust aerosol under wet deposition conditions. The aim of this study was, firstly, to deduce the relationship between iron solubility and the mineralogical composition of dust particles and secondly to investigate a potential relationship between the iron solubility and the mineralogical splitting up that arise during atmospheric transport.

\section{Materials and Method}

\subsection{Minerals Characterization}

[4] Dust is mainly composed of a mixture of minerals such as clays, quartz and feldspars, but their relative contents are variable according to the collected area. Table 1 gives the mineralogical composition of African dust collected over Atlantic Ocean and Mediterranean. Among the clay group that represents between 48 and $82 \%$ of the total aerosol mass, illite and kaolinite are the dominant minerals. Smectite and chlorite are detected in most of samples but in very low concentrations. Among the non-clay minerals, quartz is the most common and ranges between 10 and 20\%. Calcite and feldspars are always found in dust but in smallest proportions. Total iron content expressed as a percentage of the sample mass is around 4 to $7 \%$ depending on the source area. Iron in dust may be in the form of oxides (hematite, magnetite) and hydroxides (goethite) but is also present in aluminosillicate minerals. Lafon et al. [2004] have measured the percentage of free-iron (iron in (hydr-)oxide) relative to the sample mass in dust aerosols: they found between 2.8 to $5 \%$ according to their origin and 
Table 1. Mean Mineralogical Composition of African Dust ${ }^{\mathrm{a}}$

\begin{tabular}{|c|c|c|c|c|c|c|c|}
\hline Site $^{\mathrm{b}}$ & Illite & Kaolinite & Smectite & Other Clay & $\Sigma$ Clay & Feldspars & Others \\
\hline 1 & 51,7 & 5,6 & - & 4,2 & 61,5 & 8,1 & 30,4 \\
\hline 2 & - & - & - & & 48,0 & 6,6 & 45,4 \\
\hline 3 & - & - & - & & 44,0 & 6,1 & 49,9 \\
\hline 4 & 39,3 & 3,6 & 6,5 & 9,9 & 59,3 & 3,6 & 37,8 \\
\hline 5 & 40,8 & 7,6 & 12,3 & 7,3 & 67,9 & 3,4 & 29,3 \\
\hline 6 & 34,3 & 12,5 & 27,3 & 8,3 & 82,3 & 2,5 & 16,4 \\
\hline
\end{tabular}

${ }^{\mathrm{a}}$ Relative mass content is given in $\%$.

bites: 1, collected in Sal Island 9 [Glaccum and Prospero, 1980]; 2, collected in Senegal Coast [Johnson, 1979]; 3, collected in Atlantic [Johnson, 1979]; 4, collected in Spain (origin from Atlas [Avila et al., 1997]); 5, collected in Spain (origin from Western Sahara [Avila et al., 1997]); 6, collected in Spain (origin from Central Algeria [Avila et al., 1997]).

the free iron- to-the structural iron (iron trapped in the crystal lattice of aluminosilicates) ratio is often around 1.

[5] With these results in mind, we made the choice to study dissolution of most of the minerals present in dust that content iron, i.e. 2 feldspar, 3 iron (hydr-)oxide, 6 clay samples (Table 2). For each mineral, X fluorescence spectrometry analyses have been conducted to determine iron content and specific surface have been measure with the BET gas adsorption method [Fagerlund, 1973]. Results of the analysis and origin of the minerals are given in Table 2.

\subsection{Dissolution Experiment}

[6] $10 \mathrm{mg}$ of crushed mineral (particles $<100 \mu \mathrm{m}$ ), precisely weighed, was put into $250 \mathrm{ml}$ of Milli-Q water acidified at $\mathrm{pH} 2$ with nitric acid (NormatonTM), this acid is chosen because it is commonly found in rainwater [ $\mathrm{Li}$ and Aneja, 1992]. After $60 \mathrm{~min}$ of contact time between acidified water and mineral particles with shaking, the solution was filtered through a $0.2 \mu \mathrm{m}$ polycarbonate filter. Dissolved iron concentration (DFe) in the filtered sample was analyzed by GFAAS (ATI-Unicam 929) [Sofikitis, 2004]. Multi-elementary analysis of the dissolved phase was made by ICP-AES (PE Optima 3000) [Desboeufs et al., 1999]. All handling was performed in an ultra clean laboratory (class $<$ 1000 ) under ultra clean laminar flow benches (class $<10$ ). The iron solubility $\left(\% \mathrm{Fe}_{\mathrm{S}}\right)$ is calculated as follows: $\% \mathrm{Fe}_{\mathrm{S}}=$ $100 \times\left(\mathrm{DFe} / \mathrm{Fe}_{\text {tot }}\right)$ where $\mathrm{Fe}_{\text {tot }}$ is the total mineral concen- tration of iron. Preliminary studies, carried out in atmospheric conditions ( $\mathrm{pH} 4.7$ and loading charge $=10 \mathrm{mg} / \mathrm{L}$ ), showed that dissolved concentrations were close to the detection limit of the analytical methods when measuring the solubility of (hydr-)oxides [Sofikitis, 2004]. Knowing that low $\mathrm{pH}$ increases iron solubility [Desboeufs et al., 1999], we adjust the $\mathrm{pH}$ of the aqueous phase to 2 to obtain enough iron to be above our detection limit. The particulate loading was fixed to $40 \mathrm{mg} / \mathrm{L}$. The ratio of the iron solubility between oxides and clays measured at $\mathrm{pH} 4.7$ is approximately 2 orders of magnitude lower than the ratio at $\mathrm{pH} 2$ [Sofikitis, 2004]. Thus, in this work, iron solubility in natural waters will be overestimated, and not necessarily in a linear fashion, meaning that the relationship between solubility at $\mathrm{pH} 4.7$ and $\mathrm{pH} 2$ is not linear. Thus, in this work, iron solubility could be overestimated for oxides.

\section{Results and Discussion}

[7] The results, presented in Table 3, emphasize that the solubility of iron (hydr-)oxides is much lower than for aluminosilicate minerals. Thus it appears that the iron (hydr-)oxides which are the richest in iron, release the least iron into water in comparison with the clays or the feldspars. In order to consider if iron solubility is related to the $\mathrm{Fe}_{\text {tot }}$ in the minerals, $\% \mathrm{Fe}_{\mathrm{S}}$ versus $\mathrm{Fe}_{\text {tot }}$ for each mineral is plotted in Figure 1. Figure 1 emphasizes an exponential

Table 2. Physical and Chemical Properties of Minerals Used

\begin{tabular}{|c|c|c|c|c|c|}
\hline Mineral (Reference) & Origin & Class & Chemical Formula & $\begin{array}{l}\text { Fe Fraction, } \\
\% \mathrm{w} / \mathrm{w}\end{array}$ & $\begin{array}{l}\text { BET Specific } \\
\text { Surface, } \mathrm{m}^{2} \mathrm{~g}^{-1}\end{array}$ \\
\hline Goethite (HS36) ${ }^{\mathrm{a}}$ & $\begin{array}{l}\text { Biwabik, } \\
\text { Minnesota }\end{array}$ & $\begin{array}{c}\text { Iron } \\
\text { hydroxide }\end{array}$ & $\mathrm{FeOOH}$ & 62,9 & 1 \\
\hline Magnetite $\left(\right.$ GDS69) ${ }^{\mathrm{a}}$ & $\begin{array}{l}\text { Republic, } \\
\text { Michigan }\end{array}$ & Iron oxide & $\mathrm{Fe}_{2} \mathrm{O}_{4}$ & 77,4 & 1 \\
\hline Hematite $^{\mathrm{b}}$ & - & Iron oxide & $\mathrm{Fe}_{2} \mathrm{O}_{3}$ & 57,5 & 9 \\
\hline Illite $1\left(\right.$ API35) ${ }^{\mathrm{a}}$ & Fithian, Illinois & Clay & $\left(\mathrm{K}, \mathrm{H}_{3} \mathrm{O}\right) \mathrm{Al}_{2}\left(\mathrm{Si}_{3} \mathrm{Al}\right) \mathrm{O}_{10}\left(\mathrm{H}_{2} \mathrm{O}, \mathrm{OH}\right)_{2}$ & 4,65 & 45 \\
\hline Illite (API36) $2^{\mathrm{a}}$ & Rochester, N.Y. & Clay & $\left(\mathrm{K}, \mathrm{H}_{3} \mathrm{O}\right) \mathrm{Al}_{2}\left(\mathrm{Si}_{3} \mathrm{Al}\right) \mathrm{O}_{10}\left(\mathrm{H}_{2} \mathrm{O}, \mathrm{OH}\right)_{2}$ & 3,38 & 33 \\
\hline $\begin{array}{l}\text { Montmorillonite } \\
\text { (smectite API25) }\end{array}$ & Osage, Wyoming & Clay & $(\mathrm{Na}, \mathrm{Ca})_{0,3}(\mathrm{Al}, \mathrm{Mg})_{2} \mathrm{Si}_{4} \mathrm{O}_{10}(\mathrm{OH})_{2}, \mathrm{nH}_{2} \mathrm{O}$ & 2,55 & 19 \\
\hline Nontronite $^{\mathrm{a}}$ (smectite) & $\begin{array}{l}\text { Allentown, } \\
\text { Pennsylvania }\end{array}$ & Clay & $\mathrm{Na}_{0,3} \mathrm{Fe}_{2}(\mathrm{Si}, \mathrm{A} 1)_{4}(\mathrm{OH})_{2} \mathrm{O}_{10}$ & 23,0 & 6 \\
\hline Beidellite $^{\mathrm{b}}$ (smectite) & - & Clay & $\begin{array}{c}\left(\mathrm{Na}, \mathrm{Ca}{ }_{0,5}\right)_{0,3} \mathrm{Al}_{2}(\mathrm{Al}, \mathrm{Si})_{4} \mathrm{O}_{10}(\mathrm{OH})_{2} \\
\mathrm{nH} 2 \mathrm{O}\end{array}$ & 6,50 & 36 \\
\hline Oligoclase $^{\mathrm{b}}$ & - & Feldspar & $(\mathrm{Na}, \mathrm{Ca})(\mathrm{Al}, \mathrm{Si}) \mathrm{O}_{8}$ & 0,54 & - \\
\hline Orthoclase $^{\mathrm{b}}$ & - & Feldspar & $\mathrm{K} \mathrm{Al} \mathrm{Si} \mathrm{O}_{8}$ & 0,13 & - \\
\hline
\end{tabular}

${ }^{\mathrm{a}}$ From Ward's natural science.

"From " la galerie des minéraux " of Paris. 


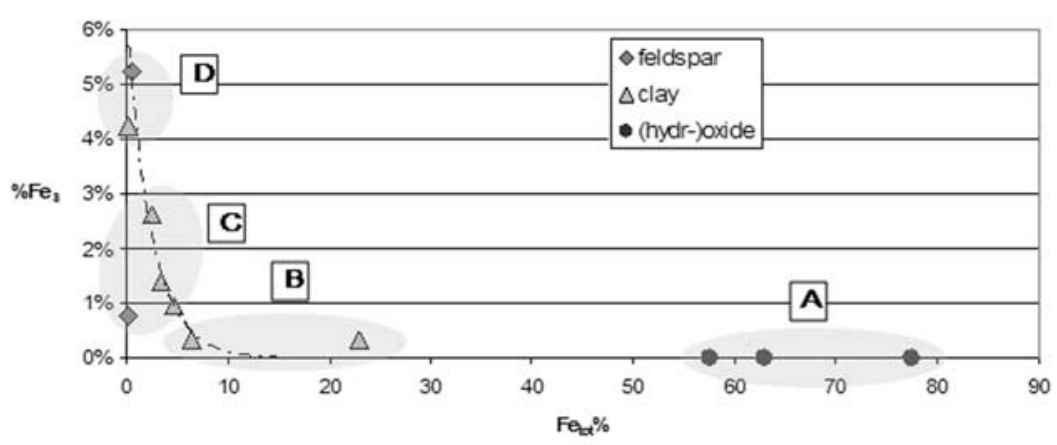

Figure 1. Percentage of soluble iron $\left(\% \mathrm{Fe}_{\mathrm{S}}\right)$ as a function of total iron content of the mineral $\left(\mathrm{Fe}_{\text {tot }}\right.$ in $\left.\%\right)$.

decrease of iron solubility with the mineral iron content increase. This trend has been already observed by Zhuang et al. [1992] for aerosol samples collected over Pacific Ocean. These authors have suggested that iron chemical form in aerosol, i.e. (i) iron in aluminosilicate phase and (ii) iron in hydroxide phase, could be an explanation of this trend. Moreover, the low dissolution rate of hydrous oxides in comparison with aluminiosilicates is well known in aquatic surface geochemistry [Stumm and Furrer, 1987]. Most of the dissolution reactions of minerals are critically dependent on the coordinative interactions taking place on surface [Wieland et al., 1988]. In consequence, the exponential trend of iron solubility could be linked to the type of chemical bonds in which iron atoms are implied in the mineral, $\mathrm{Fe}_{\text {tot }}$ being a simple tracer of type of bonding. To investigate the role of the type of bond, dissolved iron concentrations have been compared to other dissolved elements $(\mathrm{X}=\mathrm{Al}, \mathrm{K}$ or $\mathrm{Mg})$. A ratio (DX/DFe) $/(\mathrm{X}$ tot/Fetot) which is close to 1 shows that the $\mathrm{Fe}$ and $\mathrm{X}$ are dissolved according to a similar dissolution process, while a ratio $<$ or $>1$ emphasizes a preferential dissolution for $\mathrm{Fe}$ or $\mathrm{X}$ respectively. On this calculation basis, 4 types of dissolved iron behaviour can be distinguished (Figure 1 and Table 3):

[8] 1. Iron (hydr-)oxides are composed by $\mathrm{Fe}, \mathrm{H}$ and $\mathrm{O}$ (Case A). In these minerals, iron is inferred to be in the strong Fe-O lattice bonds.
[9] 2. The case of nontronite and beidellite (Case B) for which Fe dissolution presents a comparable behaviour to Al. Indeed, for these minerals, iron is known to be generally in substitution of this element in the crystalline network [Deer et al., 1966]. Thus, Fe is located in the octahedral (Albearing) or tetrahedral (Si-bearing) layers bound by covalent bonds.

[10] 3. The minerals where Fe is dissolved in an identical pattern to $\mathrm{K}$ or $\mathrm{Mg}$ (e.g. orthoclase, illites and montmorillonite (case $\mathrm{C}$ )), where Fe substitutes for $\mathrm{Mg}$ or $\mathrm{K}$ In this case, ionic bonds hold $\mathrm{Fe}$ in the lattice.

[11] 4. In the minerals where Fe is in the form of impurities such as kaolinite and oligoclase, no relationship of Fe dissolution with others elements is observed. (Case D). Mermut and Cano [2001] provide chemical analyses of the kaolinite $\mathrm{KGa} 1$ and show that the Fe content corresponds to a contamination by amorphous free iron impurities.

[12] The solubility is the highest for the minerals where the $\mathrm{Fe}$ is probably found as amorphous impurities and the lowest for the (hydr-)oxides where iron is bound by covalent bonds in the crystalline lattice (Figure 1). For the intermediate solubility values, $\% \mathrm{Fe}_{\mathrm{S}}<1 \%$ if it substitutes $\mathrm{Si}$ and $\mathrm{Al}$ in the lattice and $>1 \%$ if it replaces alkaline elements as interlayer ions.

[13] Baker and Jickells [2006] claim recently changes in the mean surface area to volume ratio of the mineral

Table 3. Solubility, Specific Surface Effect, and Comparison Between Dissolved Fraction of Iron and Other Elements (Al, K and Mg)

\begin{tabular}{|c|c|c|c|c|c|}
\hline Mineral & $\% \mathrm{Fe}_{\mathrm{s}}$ & $\% \mathrm{Al}_{\mathrm{s}} / \% \mathrm{Fe}_{\mathrm{s}}$ & $\% \mathrm{~K}_{\mathrm{s}} / \% \mathrm{Fe}_{\mathrm{s}}$ & $\% \mathrm{Mg}_{\mathrm{s}} / \% \mathrm{Fe}_{\mathrm{s}}$ & $\% \mathrm{Fe}_{\mathrm{s}} / \mathrm{SS}, \% \mathrm{~m}^{-2} \mathrm{~g}^{1}$ \\
\hline \multicolumn{6}{|c|}{ Case A } \\
\hline Magnetite & 0,003 & - & - & - & 0,003 \\
\hline Goethite & 0,005 & - & - & - & 0,005 \\
\hline Hematite & 0,010 & - & - & - & 0,001 \\
\hline \multicolumn{6}{|c|}{ Case B } \\
\hline Nontronite & 0,34 & 3 & 135 & 81 & 0,057 \\
\hline Beidellite & 0,34 & 3 & 282 & 622 & 0,01 \\
\hline \multicolumn{6}{|c|}{ Case C } \\
\hline Orthoclase & 0,76 & 0,1 & 1 & 3 & - \\
\hline Illite 1 & 0,95 & 0,1 & 2 & 3 & 0,02 \\
\hline Illite 2 & 1,39 & 0,1 & 3 & 8 & 0,04 \\
\hline Montmorillonite & 2,60 & $\mathrm{udl}^{\mathrm{a}}$ & 12 & 5 & 0,14 \\
\hline \multicolumn{6}{|c|}{ Case D } \\
\hline Kaolinite & 4,26 & 0,1 & $\mathrm{udl}^{\mathrm{a}}$ & $\mathrm{udl}^{\mathrm{a}}$ & 0,31 \\
\hline Oligoclase & 5,25 & 0,02 & $\mathrm{udl}^{\mathrm{a}}$ & $\mathrm{udl}^{\mathrm{a}}$ & - \\
\hline
\end{tabular}

${ }^{\mathrm{a}}$ Dissolved fraction under detection limit of ICP-AES. 
Table 4. Experimental Estimation of Iron Solubility and Contribution of Each Mineral Group to Total Dissolved Iron

\begin{tabular}{|c|c|c|c|c|c|}
\hline Mineral Class & Studied Mineral & $\begin{array}{c}\text { Mean DFe, }{ }^{a} \\
\mathrm{nM}\end{array}$ & $\begin{array}{l}\text { Percent Mineral } \\
\text { in Aerosol }\end{array}$ & $\begin{array}{c}\text { Corrected DFe }^{\mathrm{c}} \\
\mathrm{nM}\end{array}$ & $\begin{array}{l}\text { Percent } \\
\mathrm{DFe}^{\mathrm{d}} \\
\end{array}$ \\
\hline Clays (illite) & Illite1, Illite2 & 326 & 45 & 147 & 67,4 \\
\hline Clays (kaolinite) & Kaolinite & 72 & 7 & 5 & 2,3 \\
\hline Clays (smectite) & $\begin{array}{c}\text { Nontronite, } \\
\text { Beidellite, } \\
\text { Montmorillonite }\end{array}$ & 391 & 15 & 59 & 27,0 \\
\hline Feldspars & $\begin{array}{l}\text { Oligoclase, } \\
\text { Orthoclase }\end{array}$ & 105 & 6 & 6 & 2,8 \\
\hline Iron (hydr-)oxides & $\begin{array}{c}\text { Hematite, Goethite, } \\
\text { Magnetite }\end{array}$ & 27 & 4 & 1 & 0,5 \\
\hline
\end{tabular}

${ }^{\mathrm{a}}$ Mean $\mathrm{DFe}=$ mean dissolved Fe amount.

${ }^{\mathrm{b}}$ Usual mineral composition of African dust (see Table 1).

${ }^{\mathrm{c}}$ Corrected $\mathrm{DFe}=($ mean DFe $) *($ mineral \% in aerosol $)$.

${ }^{\mathrm{d}}$ Contribution of the mineral group to the total dissolved iron $=\% \mathrm{DFe}=($ corrected $\mathrm{DFe}) * 100 /(\Sigma$ corrected $\left.\mathrm{DFe})\right)$.

aerosols population, caused by progressive removal of larger particles during transport, account for the trend in aerosol Fe solubility. As mineral particles become smaller, a greater proportion of their volume is exposed and therefore available for dissolution. Such phenomenon is known in the geochemical area as surface-controlled dissolution [Stumm and Furrer, 1987]. In order to consider the specific surface effect, specific surfaces (SS) have been compared to the iron solubility by determining the ratio $\% \mathrm{Fe}_{\mathrm{S}} / \mathrm{SS}$ (Table 3 ). No relationship is observed between iron solubility and specific surface. The ratio $\% \mathrm{Fe}_{\mathrm{S}} / \mathrm{SS}$ is under $0,005 \% \cdot \mathrm{m}^{-2}$.g for iron (hydr-)oxide while for clays it is at least twice much higher, that means the great difference in iron solubility between these two mineral classes is not linked with the specific surface. Globally, specific surface effect on iron solubility doesn't seem to be as much significant as the chemical structure of solid phase. In consequence, it appears that iron solubility is closely linked to the mineralogical composition of aerosol.

\section{Biogeochemical Implications}

[14] As iron oxides and hydroxides are composed by more than $50 \%$ of iron, they are usually considered as the main suppliers of dissolved iron resulting from dust particles dissolution. For example, several models predicting atmospheric dust deposition of soluble iron in ocean assume that soluble Fe within the dust mode is produced primarily through the dissolution of hematite [Meskhidze et al., 2003; Fan et al., 2006]. Our work allows us to check this hypothesis by calculating the contribution of each mineral found in dust to the total dissolved iron. Under the specific condition of this study, the concentration of dissolved iron coming from dust dissolution was estimated for an average mineralogical composition that was calculated using the mean values of the mineralogical composition from Table 1 (see Table 4). The relative mass content of iron (hydr-) oxides in dust is estimated with the dataset from Lafon et al. [2004]. For each mineral, concentrations of dissolved iron were calculated from their iron solubility values multiplied by their relative iron fraction in dust aerosols. Thus, the contribution of each mineral to the total dissolved iron is summarized in Table 4 . These results point out the large contribution of clays, which represents more than $96 \%$ of the total dissolved iron, despite their low iron content but thanks to their high iron solubility. On the other hand, the input from (hydr)oxides dissolution is quasi-negligible. Literature shows that reactions of ferric iron from oxides with organic species such as oxalate or by photochemical processes could play a significant role in producing soluble iron (e.g., Siffert and Sulzberger, 1991). Siffert and Sulzberger [1991] show that iron solubility in presence of oxalate increases by a factor 10 upon irradiation. However, even in these favourable conditions, iron solubility could reach value around $0.5 \%$ that is always smaller than the iron solubility of clays. Our results therefore suggest that the use of iron (hydr)oxides and particularly hematite in biogeochemical models, might induce an underestimation of the dissolved iron supply and hence an overestimation of atmospheric chemical processes contribution as in the increase of the solubility during dust transport. The impact of this trend in Fe solubility will be to smooth out the strong gradients in atmospheric iron supply to the ocean, with proportionately less soluble $\mathrm{Fe}$ delivered to areas close to major dust sources and more to remote areas, relative to most current models, which use a fixed value for aerosol $\mathrm{Fe}$ solubility. To provide realistic iron solubility values from mineral dust in wet deposition to the biogeochemical models, future work is planned in close conditions of a rainwater composition ( $\mathrm{pH}$, organic ligands) on each mineral. Moreover, the high solubilities observed in dust aerosols [Mahowald et al., 2005] cannot be simply explained from our results; the contribution of the atmospheric processing or others sources of soluble iron need to be evaluated. Atmospheric process acting on mineralogical composition may produce more soluble matter. In consequence, further dissolution experiments on dust with various mineralogical compositions collected in source areas and after transport are indispensable to distinguish the effect of dust origin mineralogy and atmospheric processing. Finally, this work suggests that it is necessary to follow the mineralogy in the atmosphere, and its evolution with transport, in order to parameterize iron solubility in models.

\section{References}

Avila, A., I. Queralt-Mitjans, and A. Alrcona (1997), Mineralogical composition of African dust delivered by red rains over northeastern Spain, J. Geophys. Res., 102(D18), 21,977-21,996.

Baker, A. R., and T. D. Jickells (2006), Mineral particle size as a control on aerosol iron solubility, Geophys. Res. Lett., 33, L17608, doi:10.1029/ 2006 GL026557. 
Chen, Y., and R. L. Siefert (2004), Seasonal and spatial distributions and dry deposition fluxes of atmospheric total and labile iron over the tropical and subtropical North Atlantic Ocean, J. Geophys. Res., 109, D09305, doi:10.1029/2003JD003958.

Deer, W. A., R. A. Howie, J. Zusman (1966), An Introduction to the Rock Forming Minerals, Longman, London.

Desboeufs, K. V., R. Losno, F. Vimeux, and S. Cholbi (1999), The pHdependent dissolution of wind-transported Saharan dust, J. Geophys. Res., 104(D17), 21,287-21,299.

Desboeufs, K. V., R. Losno, and J. L. Colin (2001), Factors influencing aerosol solubility during cloud processes, Atmos. Environ., 35, 35293537.

Duce, R. A., and N. W. Tindale (1991), The atmospheric transport of iron and its deposition in the ocean, Limnol. Oceanogr., 36(8), 1715-1726.

Fagerlund, G. (1973), Determination of specific surface by the BET method, Mater. Struct., 6(3), 239-245.

Fan, S.-M., W. J. Moxim, and H. Levy II (2006), Aeolian input of bioavailable iron to the ocean, Geophys. Res. Lett., 33, L07602, doi:10.1029/ 2005 GL024852.

Gao, Y., S. Fan, and J. L. Sarmiento (2003), Aeolian iron input to the ocean through precipitation scavenging: A modeling perspective and its implication for natural iron fertilization in the ocean, J. Geophys. Res., 108(D7), 4221, doi:10.1029/2002JD002420.

Glaccum, R. A., and J. M. Prospero (1980), Saharan aerosols over the tropical North Atlantic mineralogy, Mar. Geol., 37, 295-321.

Hand, J. L., N. M. Mahowald, Y. Chen, R. L. Siefert, C. Luo, A. Subramaniam, and I. Fung (2004), Estimates of atmospheric-processed soluble iron from observations and a global mineral aerosol model: Biogeochemical implications, J. Geophys. Res., 109, D17205, doi:10.1029/ 2004JD004574.

Jickells, T. D., et al. (2005), Global iron connections between desert dust, ocean biogeochemistry and climate, Science, 308(5718), 67-71.

Jonhson, L. R. (1979), Mineralogical dispersal patterns of North Atlantic deep-sediments with particular reference to eolian dusts, Mar. Geol., 29, $335-345$.

Lafon, S., J.-L. Rajot, S. C. Alfaro, and A. Gaudichet (2004), Quantification of iron oxides in desert aerosol, Atmos. Environ., 38, 1211-1218.
Li, Z., and V. P. Aneja (1992), Regional analysis of cloud chemistry at high elevations in the eastern United States, Atmos. Environ., Part A, 26, 2001-2017.

Mahowald, N. M., A. R. Baker, G. Bergametti, N. Brooks, R. A. Duce, T. D. Jickells, N. Kubilay, J. M. Prospero, and I. Tegen (2005), Atmospheric global dust cycle and iron inputs to the ocean, Global Biogeochem. Cycles, 19, GB4025, doi:10.1029/2004GB002402.

Mermut, A. R., and A. F. Cano (2001), Baseline studies of the Clay Minerals Society source clays: Chemical analyses of major elements, Clays Clay Miner., 49(5), 381-386.

Meskhidze, N., W. L. Chameides, A. Nenes, and G. Chen (2003), Iron mobilization in mineral dust: Can anthropogenic $\mathrm{SO}_{2}$ emissions affect ocean productivity?, Geophys. Res. Lett., 30(21), 2085, doi:10.1029/ 2003GL018035.

Siffert, C., and B. Sulzberger (1991), Light-induced dissolution of hematite in the presence of oxalate: A case of study, Langmuir, 7, 1627-1634.

Sofikitis, A. (2004), Source et évolution des formes redox du fer en phase aqueuse atmosphérique, Ph.D. dissertation, Univ. Paris 7 et 12, Paris.

Stumm, W., and G. Furrer (1987), The dissolution of oxides and aluminum silicates: Examples of surface coordination-controlled kinetics, in Aquatic Surface Chemistry, edited by W. Stumm, pp. 197-200, WileyInterscience, New York.

Wells, M. L., M. M. Price, and K. W. Bruland (1995), Iron chemistry in seawater and its relationship to phytoplankton: A workshop report, Mar. Chem., 48, 157-182.

Wieland, E., B. Wehrli, and W. Stumm (1988), The coordination chemistry of weathering: III. A generalization on the dissolution rates of minerals, Geochim. Cosmochim. Acta, 52, 1969-1981.

Zhuang, G., Z. Yi, R. A. Duce, and P. R. Brown (1992), Chemistry of iron in marine aerosols, Global Biogeochem. Cycles, 6, 161-173.

S. Caquineau, Laboratoire des Formations Superficielle, Institut de Recherche pour le Developpement, 32, av Henri Varagant, F-93143 Bondy cedex, France.

J.-L. Colin, K. V. Desboeufs, and E. Journet, LISA, Universités Paris 7 et Paris 12, CNRS, 61 avenue du général de Gaule, F-94010 Créteil, France. (journet@lisa.univ-paris12.fr) 